\title{
Self-motivation challenges for student involvement in the Open Educational Movement with MOOC
}

\section{Brenda Jeanett García Espinosa', Gloria Concepción Tenorio Sepúlveda² and María Soledad Ramírez Montoya ${ }^{3}$}

\author{
1. Tecnológico de Monterrey, \\ Mexico | brenda.jgarciae@gmail.com \\ 2. Tecnológico de Estudios Superiores de Chalco (TESCHA), \\ Mexico|gloria_cts@yahoo.com.mx \\ 3. Tecnológico de Monterrey, \\ Mexico|solramirez@itesm.mx
}

\section{Recommended citation}

García, B. J., Tenorio, G. C., \& Ramírez, M. S. (2015). Self-motivation challenges for student involvement in the Open Educational Movement with MOOC. RUSC. Universities and Knowledge Society Journal, 12(1). pp. 91-103. doi http://dx.doi.org/10.7238/rusc.v12i1.2185

\begin{abstract}
This article attempts to answer the questions: What are the challenges, problems and obstacles of involving less self-motivated students in MOOCs and how do they relate to their learning connectivism? The correlations between connectivism and contextualized learning through a formative experience of the Open Educational Movement was analyzed in order to propose strategies that result in greater perseverance, active participation and retention of less self-motivated students in MOOCs. A mixed method approach was used to survey students, interview students and coordinators, and analyze relevant documents. The findings were classified as (1) Challenges: self-motivation, selfregulation abilities, extra time invested, release requirements, goals and inductive activities before the course opening, unsatisfactory identification of students, difficult activities, feedback monitoring and a platform incompatible with balancing its use with that of social networks; (2) Problems: limited information and communication technology skills, difficult feedback research in forums, uncertain peer feedback when not theory-based or scaffolded by teachers, scarce theoretical support in evidence portfolios and a lack of means to help low self-motivated or selfregulated students; (3) Main contextual obstacles: some students cannot count on their employers' support or continuous technology access, some students basic wellbeing needs are not met, and inability to contextualize learning; (4) Connectivism: students' motivation in the MOOC content and their expanding knowledge networks. Based on these findings, a MOOC design requirement template aimed at supporting students' self-motivation and self-regulation through connectivism is provided.
\end{abstract}

\section{Keywords}

self-motivation, open education movement, MOOCs, e-learning, connectivism, contextualized learning 


\section{Retos de automotivación para el involucramiento de estudiantes en el movimiento educativo abierto con MOOC}

\section{Resumen}

Este artículo indagó la siguiente cuestión: ¿cuáles son los desafíos, problemas y obstáculos para involucrar a los estudiantes menos automotivados en los MOOC y cómo se relacionan con el conectivismo de sus aprendizajes? El objetivo fue analizar las correlaciones entre el conectivismo y el aprendizaje estudiantil contextualizado, en una experiencia formativa del movimiento educativo abierto, con el fin de aportar estrategias que generen mayor perseverancia de estos estudiantes, participación activa y retención estudiantil. El método de estudio fue mixto, con aplicación de encuestas a estudiantes, entrevistas a alumnos y maestros, así como el análisis de documentos significativos. Los hallazgos se clasificaron en: (1) Desafíos: requerimiento de habilidades de automotivación, autorregulación y tiempo adicional por parte de algunos alumnos, difícil monitoreo de retroalimentaciones y actividades, falta de liberación anticipada de requerimientos, objetivos y actividades de inducción, deficiente identificación de alumnos observadores e incompatibilidad entre la plataforma y el uso de redes sociales; (2) Problemas: baja apropiación tecnológica de participantes, difícil búsqueda de retroalimentaciones específicas en los foros, portafolios de evidencias sin fundamento teórico y falta de recursos de ayuda para estudiantes de baja automotivación y autorregulación; (3) Obstáculos: falta de apoyo de los centros de trabajo para los participantes del MOOC y de acceso continuo a recursos digitales, incumplimiento de las necesidades personales básicas de los estudiantes sobre bienestar y el no contextualizar nuevos saberes; (4) Conectivismo: motivación de los participantes en sus contenidos e incremento de sus redes de saber. Con base en estos hallazgos se aporta una plantilla con requisitos de diseño de MOOC, enfocado a la automotivación y autorregulación estudiantil mediante el conectivismo.

\section{Palabras clave}

automotivación, movimiento educativo abierto, MOOC, e-learning, conectivismo, aprendizaje contextualizado 


\section{Context and theoretical framework}

The subject of formative open practices has been promoted through the Open Educational Movement by adding Open Educational Resources (OER). In the 1990s, courses, resources and materials, as well as institutions' scientific and academic production were rarely open; however, in recent years, new practices, fields of knowledge, educational practices and lifestyles have emerged, and we have seen the rise of technologies that support formative experiences such as e-learning, the Open Education Movement, the integration of OER and informal learning through communities of practice (Olcott, 2013; Sangrá \& Wheeler, 2013).

In the midst of change, OER have been integrated into connectivism through MOOCs, with inquiries about participants and e-learning models involving formative practices. For example, in MOOCs, student retention is less than 10\% (Carr, 2013), which raises interest in studying the challenges faced by its participants. Hence, this study was based on satisfactory learning, self-regulated behaviors and differentiated teaching techniques in MOOCs.

Analyzed studies concerning student behavior in e-learning reveal that a combination of various learning styles produce better academic achievement and motivation (Contreras \& Lozano, 2012), that e-learning encourages metacognition and self-regulation (Farias \& Ramírez, 2010), and that there is a need to study the developing skills required in MOOCs and knowledge contextualization problems (Ramírez, 2013). Furthermore, motivation is linked to the self-determination shown by students who perform well academically and demonstrate autonomous commitment behaviors such as self-regulated learning, goal definition and self-motivation regulation, all of which are guided and constrained by their context (Wolters, Pintrich, \& Karabenick, 2003). This connection has been achieved by the theory of self-determination, which includes the students' satisfaction of the psychological demands of autonomy, ability and affinity. It should also be taken into account that learning motivation occurs by covering the basic needs of organization, distraction reduction and the identification and contextualization of important information (Niemiec \& Ryan, 2009; Ormrod, 2005; Sangrá \& Wheeler, 2013).

Several studies have been conducted to meet these academic requisites: (1) Niemiec and Ryan (2009) suggested providing various significant bases and minimizing pressure for autonomy, assigning challenging tasks, ensuring important feedback for ability and conveying affection and respect for affinity; (2) Shroff, Vogel, and Coombes (2008) analyzed skill perception, feedback and choices that affect students' self-determination, and; (3) Fisher and Baird (2005) discovered that social networks produce affinity among students, thereby escalating their intrinsic motivation.

It is also worth mentioning that MOOCs require an enrolment and an educational platform to mobilize knowledge by OER. Since they require high regulation, they can be used individually, but in order to prosper, contributions must be shared among colleagues. They are accreditable interinstitutionally if evidence of learning is evaluated and approved; their methodology and design depends on the participants, subject, objective and program (Sangrá \& Wheeler, 2013). They are classified as CMOOCs when they are exclusively based on connectivism (students determine their commitment), or as XMOOCs when they are delivered by a university (Downes, 2012; Evans, Burritt, \& Guthrie, 2013). It is important to note that one of the professors for the MOOC used in this study also assumed command of the first one used in Latin America (Ramírez, 2013).

Connectivism joins MOOCs because collaborations develop online materials that produce knowledge according to personal needs (Coughlan \& Perryman, 2013; Olcott, 2013). Hence, knowledge must be stored in networks by 
virtue of the digital advances that have boosted the amount of data available (Downes, 2012; Siemens, 2005; Sangrá \&Wheeler, 2013).

With this background, this article presents the nature and dimension of a study aimed at analyzing the main challenges, problems and obstacles of involving less self-motivated students in MOOCs, and examining the correlations present between connectivism and contextualized student learning. The starting point of the research sought to answer: What are the challenges, problems and obstacles of involving less self-motivated students in MOOCs and how do they relate to their learning connectivism? Our objective is to find ways to yield strategies that produce a greater persistence by less self-motivated students in MOOCs and increase overall active participation and student retention.

This article describes a study based on a MOOC that was conducted for one month and was taught by a prestigious Mexican university. The university has fueled the Open Educational Movement in Latin America by creating e-books, a DAR repository and a Temoa indexing system, and by training researchers and offering online courses through its virtual university (Ramírez, 2013). The MOOC was on the topic of the Open Educational Movement. More than 20,400 people from 52 countries enrolled on it. Of these, 5\% remained active with assistance from $25 \%$ of the initial teacher assistants (800 volunteers). The MOOC included administrative forums that promoted connectivity and granted access to a program with participation instructions, self-assessment rubrics and teachers' OER that required student review in order to develop and distribute digital learning evidence (Ramírez \& Burgos, 2013a; 2013b). Finally, the students were required to develop an electronic portfolio (e-portfolio) for evaluation by their peers.

\section{Research method}

The study was based on mixed method research starting with a quantitative approach and followed by a qualitative one, in which the latter had an exploratory design and greater importance (Creswell \& Plano, 2011; Onwuegbuzie, Burke, \& Collins, 2011; Tashakkori \& Teddlie, 2003). In pursuance of inquiries, a triple entry table was developed and ideal sources of information were noted. Its data was corroborated against the selected theoretical framework. Thus, an interview and an observation grid were designed. Using the triangulation technique, the information was verified, granting validity to the qualitative data (Valenzuela \& Flores, 2012).

In this context, a pilot test was deployed to ensure reliability of the qualitative data collected. The validity of the interviews was obtained by promoting acceptance and trust among the interviewees, whose responses were transcribed in order to be analyzed using associative member checking. Meanwhile, fingerprint analysis included an observation grid, with categories and subcategories of unit analysis attaining validity by determining object characteristics, and with the results of statistical records analysis by examining figures, thereby making a new observation (Giroux \& Tremblay, 2009; Valenzuela \& Flores, 2012).

Moreover, the MOOC organizers applied massive surveys and context (used in self-evaluations) and learning rubrics (used in the final peer evaluation) authenticated by a group of experts. Their reliability was given by the active participants' stability; thus, the figures obtained were processed in graphs, statistics and electronic spreadsheets to validate reports (Creswell \& Plano, 2011) 


\section{Identification of samples}

The MOOC studied initially had two teachers, two coordinators, 800 teacher assistants, OER, activities and instructions in order to develop and disseminate knowledge evidence. Its finite and discrete population served as a sample for the quantitative analysis and consisted of $5 \%$ of the students who actively participated in the standardized surveys designed by the MOOC organizers (Ramírez \& Burgos, 2013c).

On the other hand, the qualitative, non-probabilistic, atypical sample was based on metainferences and on the stratification of the population. It was consolidated by the representativeness and availability of the sample. This included two coordinators, four volunteer students, and three of each of the following objects: OER, products and interactions in social networks and forums (Collins, 2003; Valenzuela \& Flores, 2012).

\section{Analysis and results}

The massive surveys revealed student activity in the MOOC (Table 1). Although it was evident that the course had been clearly outlined, its demands were complex for some, which correlated with their low information and communication technology (ICT) appropriation and/or their poor command of English (Table 2). On the other hand, peer evaluation, which is common in MOOCs because of their size (Martin, 2012), consisted of participants mutually giving numerical ratings according to their perception of the last evidence portfolio. Since this was the only grade collected, the marks were statistically analyzed. This analysis showed a single mode and only one peak (Table 3), and resulted in a grade bar chart (Figure 1) with a leptokurtic distribution, negative skew and positive kurtosis with a curve asymmetry to the right, where the variance revealed minimal grade dispersion (Aiken, 2003; Molina \& Rodrigo, 2009; Valenzuela, 2006), as the grades were mostly high.

Table 1. Student activity in the MOOC

\begin{tabular}{|c|c|c|}
\multicolumn{2}{|c|}{ People } & Description \\
\hline Number & Percentage & Began the MOOC immediately after enrolment \\
\hline 17,550 & $88 \%$ & Performed no activities and did not accredit the course \\
\hline 16,450 & $82 \%$ & Mean that carried out weekly activities \\
\hline 1,100 & $5 \%$ & Conducted the final evaluation (peer evaluation) \\
\hline 802 & $4 \%$ & Accredited the course \\
\hline 868 & $4.3 \%$ & Delivered weekly activities and final evaluation \\
\hline 543 & $3 \%$ &
\end{tabular}


Table 2. Highest student incidences on skills and technology appropriation

\begin{tabular}{|c|c|c|}
\hline Classification & Percentage & Description \\
\hline \multirow{4}{*}{$\begin{array}{l}\text { ICT appropriation by } \\
\text { respondents }\end{array}$} & $76 \%$ & Have e-learning experience \\
\hline & $42 \%$ & Possess knowledge regarding online information credibility \\
\hline & $41 \%$ & Have advanced ICT skills (70\%-80\%) \\
\hline & $38 \%$ & Possess intermediate knowledge (50\%-60\%) on OER development \\
\hline \multirow{2}{*}{ Students'skills } & $49 \%$ & Describe themselves as self-taught \\
\hline & $39 \%$ & Members with basic English skills (30\%-40\%) \\
\hline
\end{tabular}

Table 3. Peer evaluation results

\begin{tabular}{|c|c|c|c|c|c|c|c|}
\hline \multicolumn{5}{|c|}{ Measures of } & & \multirow{2}{*}{\multicolumn{2}{|c|}{.oefficient of }} \\
\hline \multirow[b]{2}{*}{ Mean } & \multicolumn{2}{|c|}{ Central Tendency } & \multicolumn{2}{|c|}{ Dispersion } & & & \\
\hline & Median & Mode & $\begin{array}{l}\text { Standard } \\
\text { deviation }\end{array}$ & Variance & Bias & Kurtosis & Variance \\
\hline 8.18 & 9 & 10 & 2.03 & 4.11 & -1.89 & 4.74 & 0.50 \\
\hline
\end{tabular}

Figure 1. Peer assessment score bar chart

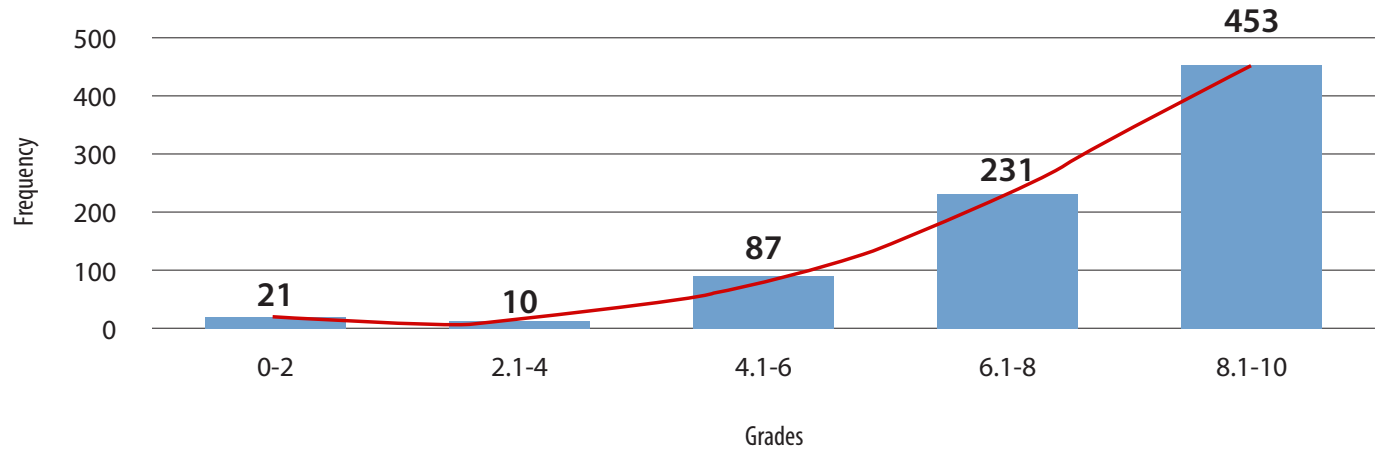

Table 4. Most commonly mentioned student problems relating to the use of knowledge acquired within the MOOC

\begin{tabular}{|c|c|}
\hline Percentage & Description \\
\hline $63 \%$ & The status of their workplace with respect to the Open Education Movement is zero or beginner \\
\hline $30 \%$ & It is hard for them to adapt an OER created in a language other than their own \\
\hline $22 \%$ & It takes them a lot of time to adapt another author's OER for use in their educational practice \\
\hline $16 \%$ & OER created by other people/institutions do not address the issues that they need to address \\
\hline $10 \%$ & OER created by other institutions cannot be applied in theirs \\
\hline
\end{tabular}


It is also important to mention that connectivism's collectivity increased the scope of the students' personal networks of knowledge, which was evidenced when they shared portfolios (appreciated by 63\%), information in forums, and established working groups in social networks, perceiving 43\% affinity. This is because in connectivism, knowledge is stored in networks. Given the amount of information flowing nowadays, such networks may include communities of learning with collaborative social ties to create constructivist knowledge (Downes, 2012; Fisher \& Baird, 2005; Siemens, 2005).

A low percentage of accreditations (Table 1) was detected as a result of partial ICT appropriation (Table 2), on the grounds that certain skills are required on MOOCs (Ramírez, 2013) which most of the enrolled students did not possess (Mupinga, Nora, \& Yaw, 2006). Disparities between the MOOC's purposes and student expectations discouraged the latter. To avoid this, the course must distinguish its objective, subject, format, program and type of participants, and in this fashion, organizers must choose adequate ICTs to meet students' goals and have a broader reach (Ransdell, 2009).

The low quality of peer feedback demotivated students. The large number of participants did not allow everyone to have a teacher assistant, and those who were available were not permanent or lacked adequate expertise. Although students should receive accurate and meaningful comments (Shroff, Vogel, \& Coombes, 2008), the size of the MOOC group merits observations among peers, which may be imprecise (Martin, 2012).

Students who do not contextualize new knowledge are discouraged. In this course, 63\% of the participants worked in a low ICT appropriation environment (Table 4). In spite of people's self-determination, their contexts limit them (Wolters, Pintrich, \& Karabenick, 2003) and, in order to inspire motivation, information must be contextualized (Ormrod, 2005).

Self-motivation can be encouraged in MOOCs if they include attractive subjects, appropriate assessments and connectivism. This was noticeable when the students found the latter, meeting their own and the MOOC's OER goals through connectivism, and situating new learning (Niemiec \& Ryan, 2009). Nonetheless, students who were technologically behind used the MOOC inductively. Its autonomy allowed learning customization and provided tools for academically weak students to improve their understanding.

MOOCs instigate self-regulation when their members set goals to complete strenuous tasks using selfassessments, rubrics and instructions. The self-motivated students' commitment allowed them to learn and organize their learning by focusing on important information. Virtual activities reinforce self-regulation (Farías \& Ramírez, 2010) and reflective qualities, making it crucial to offer tools that encourage them, since in most cases they can be assimilated (Contreras \& Lozano, 2012; Wolters, 2010).

The MOOC's educational platform has an impact on the generated learning. One can learn more and quicker with the user-friendly environment of CMOOCs, if data validity is discerned; otherwise, only the formality of XMOOCs will be reliable. Finally, educational platforms may become confusing if they control all activities, since formal systems are not necessarily required to disseminate knowledge (Downes, 2012).

\section{Discussion and conclusions}

This section presents the challenges, problems and obstacles of involving less self-motivated students in MOOCs. It subsequently explains how students relate to their learning connectivism. Finally, it presents the findings and provides recommendations for future studies concerning this type of course. 
Challenges of involving less self-motivated students in MOOCs: (1) students that do not have a high proficiency in the language used on the platform or are unfamiliar with MOOCs or their educational environment need additional time to cover course objectives, look up meanings, and explore and learn about the tools they have to use; (2) self-regulation and self-motivation skills are requirements to perform successfully in the MOOCs; (3) a lack of thorough feedback and monitoring activities, due to the size of MOOCs, lead to student dropout or inactivity; (4) failure to release inductive activities sooner and prepare students, reducing scan time once the MOOC begins; (5) pre-course information stating clearly defined objectives and language requirements to increase student satisfaction regarding learning expectations and student retention; (6) designing or selecting a MOOC educational platform that balances its use with that of social networks for knowledge construction, and; (7) including more social networking and interactive activities.

Problems of involving less self-motivated students in MOOCs: (1) cybernetic and e-portfolio sharing difficulties due to some students scant ICT appropriation; (2) difficult quest for specific feedback in forums because of the MOOC's large size; (3) uncertain peer feedback quality if not endorsed by teachers or theoretically supported; (4) some evidence portfolios with no theoretical background were useless to the rest of the group, and; (5) it did not include objectives to identify and timely support students whose motivation and self-regulation skills were low.

Obstacles of involving less self-motivated students in MOOCs (predominantly contextual aspects): (1) students low workplace support discouraged their participation and undermined the application of recently acquired knowledge, but if students had suitable ICT appropriation, they would continue constructing and applying their knowledge personally and professionally through connectivism; (2) inconsistent ICT access for some students discouraged them by not being able to comply with their evidence portfolio, and; (3) a failure to meet some students basic personal wellbeing needs, or their inability to contextualize new knowledge due to the absence of such demands, discouraged them and led students to drop out.

It is noteworthy that in this course connectivism: (a) motivated members by stimulating interest in its content through forums when students updated and obtained new knowledge through interactions with others, (b) along with the MOOC's autonomy, promoted study group development for sharing OER and exchanging data in social networks and other systems, resulting in a knowledge network that could continue growing on the completion of the MOOC.

This study's goal was fulfilled by designing a MOOC requirements template. The template focused on selfmotivation and student self-regulation through connectivism (Table 5). Its use can generate flexible MOOC designs based on connectivism, which perceive learning styles, include OER, methodologies to meet students' expectations, help them overcome learning inconsistencies, and support self-regulation and self-motivation. 
Table 5. Template design of MOOC requirements focused on self-motivation and student self-regulation through connectivism

\begin{tabular}{|c|c|c|}
\hline Type of activity & Activity detail & $\begin{array}{l}\text { OER support } \\
\text { activities }\end{array}$ \\
\hline Induction & Provide at least five activities expressing and justifying its early release date. & YouTube, etc. \\
\hline Interactive & $\begin{array}{c}\text { Trial and error tests. Provide at least one activity per week other than the synchronous } \\
\text { sessions. }\end{array}$ & Survey Monkey, etc. \\
\hline $\begin{array}{l}\text { Recognize low self-regulated } \\
\text { or self-motivated students }\end{array}$ & Describe and justify the procedure to identify such students. & Surveys, etc. \\
\hline Self-regulation promotion & $\begin{array}{l}\text { Generalized or voluntary call to identify low self-regulated students to perform } \\
\text { activities such as reducing distractions, improving organization, distinguishing } \\
\text { important information, looking for assistance, etc. Offer at least seven activities. }\end{array}$ & $\begin{array}{l}\text { Corrective activity, } \\
\text { monitoring, etc. }\end{array}$ \\
\hline Self-motivation stimulation & $\begin{array}{l}\text { Determine goals and reinforcement activities to conclude tasks, verify compliance } \\
\text { of basic human needs and psychological demands, take advantage of students' } \\
\text { excitement when being taught a new subject to make an impact on them with new } \\
\text { knowledge. Develop plans that include elements of expectation linked to student } \\
\text { ability, self-efficacy activities with self-affectivity outcomes, socialized scaffolding, } \\
\text { etc. For autonomy: offer significant and varied learning bases, recognize student } \\
\text { perceptions, minimize impositions, etc. Finally, for ability, assign challenging tasks and } \\
\text { procure important feedback. Offer a minimum of seven justified activities. }\end{array}$ & $\begin{array}{l}\text { Vary teaching } \\
\text { format, transmit } \\
\text { affection and } \\
\text { respect, include } \\
\text { formative } \\
\text { assessments, etc. }\end{array}$ \\
\hline Modeling & Examples of mandatory activities. Provide at least one per week. & $\begin{array}{l}\text { Send } \\
\text { examples }\end{array}$ \\
\hline Social network inclusion & Provide at least one per week. & Twitter, etc. \\
\hline $\begin{array}{l}\text { Distinguish students learning } \\
\text { styles }\end{array}$ & $\begin{array}{l}\text { Explain the procedure to perform the identification. Apply an initial survey that provides } \\
\text { information for grouping suggestions, examples, etc. }\end{array}$ & Surveys, etc. \\
\hline $\begin{array}{l}\text { Customized according to } \\
\text { learning styles }\end{array}$ & Provide at least one per week. & Interactive, etc. \\
\hline OER contextualization & Deliver the $\mathrm{MOOC}$ in at least one more language than the original. & Resource translation \\
\hline $\begin{array}{l}\text { Procedure to select } \\
\text { competent teacher assistants }\end{array}$ & $\begin{array}{l}\text { Explain and justify the selection procedure as well as the remedy plan in the event of } \\
\text { teacher assistant dropout. }\end{array}$ & Survey Monkey, etc. \\
\hline $\begin{array}{l}\text { Plan to ensure quality } \\
\text { feedback }\end{array}$ & Ensure that all students receive meaningful feedback. & Databases \\
\hline
\end{tabular}

The study's findings provide the following scientific contributions: (1) it is critical to promote self-determination and connectivism in MOOCs so that their members establish cybernetic connections by writing and analyzing metacognitive and horizontal contributions in forums to produce new knowledge agreements that invigorate the educational community; (2) effective learning, which results from self-regulation in MOOCs, will be produced by a smooth design that includes relevant resources, attractive subjects and aspects referred to in Table 5; (3) selfmotivation, autonomy and self-regulation in MOOCs will be fostered if self-assessments, timely and significant reviews, proper scheduling and activity differentiation are provided; (4) MOOCs are tools that especially benefit students with low purchasing power, as they bring them closer to new knowledge and enable them to construct their own; (5) for technologically lagging or academically weak students, MOOCs are tools that give autonomy, and their evaluation style can support information comprehension by updating and motivating them to work 
at their own pace; (6) in the interest of effectively integrating less self-motivated and less self-regulated students into MOOCs, a differentiation between general activities and tasks to improve these behaviors is needed, and; (7) to increase retention, students must perceive affinity and course belonging, which comes from a course meeting their expectations.

Suggestions for future MOOCs stemming from this study: (1) to focus students' questionnaires in order to identify aspects such as their self-motivation and self-regulation characteristics, learning styles and academic weaknesses; (2) to monitor students that do not participate actively and distinguish them from those who might drop out from the course in order to timely help and study the latter; (3) to look for statistics on student retention that are more useful, since some students who enroll do not start, sign up several times, etc.; (4) to meet personally with some of the MOOC attendees and course designers to address issues that, according to their perception, were not covered; (5) include weekly learning self and summative assessments, with statistical data to promptly guide teacher assistants, coordinators and teachers regarding the conceptual quality of the formative evidence portfolios.

\section{References}

Aiken, L. (2003). Tests psicológicos y evaluación. 11a ed. México, D. F.: Pearson Educación.

Carr, D. (2013). Udacity CEO says MOOC 'magic formula' emerging. Informationweek-Online. Retrieved from http:// www.informationweek.com/software/udacity-ceo-says-mooc-magic-formula-emerging/d/d-id/1111221

Collins, K. (2003). Advanced sampling designs in mixed research: current practices an emerging trends in the social and behavioral sciences. In A. Tashakkori \& C. Teddlie (Eds.), Handbook of Mixed Methods in Social \& Behavioral Research (pp. 353-377). Thousand Oaks: Sage.

Contreras, Y., \& Lozano, A. (2012). Aprendizaje auto-regulado como competencia para el aprovechamiento de los estilos de aprendizaje en alumnos de educación superior. Revista de Estilos de Aprendizaje, 10(10), 114-147. Retrieved from http://catedra.ruv.itesm.mx/handle/987654321/707

Creswell, J., \& Plano, V. (2011). Designing and conducting Mixed Method Research. 2nd ed. Thousand Oaks: Sage.

Coughlan, T., \& Perryman, L. A. (2013). Beyond the Ivory Tower: A Model for Nurturing Informal Learning and Development Communities through Open Educational Practices. RUSC. Universities and Knowledge Society Journal, 10(1), 135-150. Retrieved from doi: 10.7238/rusc.v10i1.1586

Downes, S. (2012). Connectivism and Connective Knowledge: essays on meaning and learning networks. Ottawa: National Research Council Canada. Retrieved from http://www.downes.ca/files/books/Connective_Knowledge19May2012.pdf

Evans, E., Burritt, R., \& Guthrie, J. (2013). The Virtual University: Impact on Australian Accounting and Business Education. Sydney, Australia: Institute of Chartered Accountants Australia. Retrieved from http://universitysef.org/wpcontent/uploads/2013/08/Virtual-University-Publication-final.pdf\#page=88

Farías, G., \& Ramírez, M. (2010). Desarrollo de cualidades reflexivas de profesores en formación inicial a través de portafolios electrónicos. Revista Mexicana de Investigación Educativa, 25(44), 141-162. Retrieved from http:// catedra.ruv.itesm.mx/handle/987654321/681

Fisher, M., \& Baird, D. (2005). Online learning design that fosters student support, self-regulation, and retention. Campus-Wide Information Systems, 22(2), 88-107. doi: 10.1108/10650740510587100 
Giroux, S., \&Tremblay, G. (2009). Metodología de las ciencias humanas. México D. F.: Fondo de Cultura Económica. Martin, N. (2012). MOOCs are massive. Training \& Development, 39(5), 32-33.

Molina, J., \& Rodrigo, M. (2009). Estadística descriptiva en Psicología. Valencia, Spain: University of Valencia. Retrieved from http://www.mat.uson.mx/ ftapia/Lecturas\%20Adicionales\%20\%28C\%C3\%B3mo\%20dise\%C3\%B1ar\%20 una\%20encuesta\%29/InterpretacionMedidasForma.pdf

Mupinga, D., Nora, R., \& Yaw, D. (2006). The learning styles, expectations, and needs of online students. College Teaching, 54(1), 185-189. doi: 10.3200/ctch.54.1.185-189

Niemiec, C., \& Ryan, R. (2009). Autonomy, competence, and relatedness in the classroom: Applying self-determination theory to educational practice. Theory and Research in Education, 7(2), 133-144. doi: $10.1177 / 1477878509104318$

Olcott, Jr. D. (2013). New Pathways to Learning: Leveraging the Use of OERs to Support Non-formal Education. RUSC. Universities and Knowledge Society Journal, 10(1), 151-169. Retrieved from doi: 10.7238/rusc.v10i1.1562

Onwuegbuzie, J., Burke, R., \& Collins, K. (2011). Assessing legitimation in mixed research: a new Framework. Quality \& Quantity, 45(6), 1253-1271. doi: 10.1007/s11135-009-9289-9

Ormrod, J. (2005). Aprendizaje humano. 4a. ed. Madrid, Spain: Pearson Educación.

Ramírez, M. (2013). Competencias Docentes y Prácticas Educativas Abiertas en la Educación a Distancia. Monterrey, Mexico: LULU. Retrieved from http://catedra.ruv.itesm.mx/bitstream/987654321/564/10/ebook.pdf

Ramírez, M., \& Burgos, J. (2013a). Innovación educativa con recursos abiertos. Retrieved from https://www.coursera. org/course/innovacionrea

Ramírez, M., \& Burgos, J. (2013b). Sesión 2 de participantes del curso Innovación Educativa con Recursos AbiertosTema de la sesión: Movilizando prácticas educativas abiertas: acciones [video]. 9-26-13 Hangout session. Retrieved from http://www.youtube.com/watch?v=OyXp9y6PK9k

Ramírez, M., \& Burgos, J. (2013c). Innovación educativa con recursos abiertos. Unpublished resource from MOOC: Innovación educativa con recursos abiertos.

Ransdell, M. (2009). Designscholar: Examining creative thinking in an online learning community for interior design graduate students [Doctoral dissertation], University of Florida. Retrieved from http://etd.fcla.edu/UF/ UFE0024789/ransdell_m.pdf?origin=publication_detail

Sangrá, A., \&Wheeler, S. (2013). New Informal Ways of Learning: Or Are We Formalizing the Informal? RUSC. Universities and Knowledge Society Journal, 10(1), 107-115. Retrieved from doi: 10.7238/rusc.v10i1.1689

Shroff, R., Vogel, D., \& Coombes, J. (2008). Assessing Individual-level Factors Supporting Student Intrinsic Motivation in Online Discussions: A Qualitative Study. Journal of Information Systems Education, 19(1), 111-126.

Siemens, G. (2005). Connectivism: A learning theory for the digital age. International Journal of Instructional Technology and Distance Learning, 2(1), 3-10. Retrieved from http://www.elearnspace.org/Articles/connectivism.htm

Tashakkori, A., \&Teddlie, C. (2003). Overview of Contemporary Issues in Mixed Methods Research. In: A. Tashakkori and C. Teddlie (eds.), Handbook of Mixed Methods in Social \& Behavioral Research (pp. 353-377). Thousand Oaks: Sage. Valenzuela, J. (2006). Evaluación de las instituciones educativas. México D. F.: Trillas.

Valenzuela, J., \& Flores, M. (2012). Fundamentos de investigación educativa. Vols. 2 \& 3, [eBook]. Monterrey, Mexico: Editorial Digital Tecnológico de Monterrey.

Wolters, Ch. (2010). Self-regulated learning and the 21st-century competencies. University of Houston, Department of Educational Psychology. Retrieved from http://www.hewlett.org/uploads/Self_Regulated_Learning__21st_ Century_Competencies.pdf

RUSC Vol. 12 No. 1 | Universitat Oberta de Catalunya and University of New England | Barcelona, January 2015 
Wolters, Ch., Pintrich, P., \& Karabenick, S. (2003). Assessing Academic Self-regulated Learning. Conference on Indicators of Positive Development: Definitions, Measures, and Prospective Validity. Retrieved from http://childtrends.org/wpcontent/uploads/2013/05/Child_Trends-2003_03_12_PD_PDConfWPK.pdf

\author{
About the authors \\ Brenda Jeanett García Espinosa \\ brenda.jgarciae@gmail.com \\ M.Ed. in Educational Technology from the Graduate School of Education (EGE) and B.Sc. in Industrial \\ and Systems Engineering from Tecnológico de Monterrey
}

Brenda Jeanett García Espinosa holds a M.Ed. in Educational Technology from the Graduate School of Education and a B.Sc. in Industrial and Systems Engineering, both from Tecnológico de Monterrey. She has worked in Mexican private schools teaching Science and Technology. She has taught robotics, online etiquette, digital skills and general productivity software, requiring interdisciplinary projects from students. She was a technology coach for teachers, who trained weekly in subjects such as OER selection, teaching innovation, school platform, software and hardware effective usage, etc. She was also a member of the school's committee for Science curriculum validation for 4 th to 7 th grades. Finally, as a Head Science teacher in 6th grade, she received the Startech award for teaching classes that were immersed in technology in order to promote students' critical thinking and collaborative, innovative and differentiated learning using self-created materials, OER and licensed resources, as well as requiring student creation of electronic portfolios, mobile technology projects, etc.

Einstein 2408

Contry la Silla, $7^{\circ}$ sector

Guadalupe, Nuevo León

Mexico 67173

Gloria Concepción Tenorio Sepúlveda

gloria_cts@yahoo.com.mx

Professor of B.Sc. in computer systems engineering; Tecnológico de Estudios Superiores de Chalco (TESCHA)

Gloria Concepción Tenorio Sepúlveda has a M.Ed. in Educational Technology from the Graduate School of Education (EGE) from Tecnológico de Monterrey, a bachelor's degree in Administrative Computer Science from the American Technological University (UTECA) and a Technologist in Information and Computers qualification from the Technological University of Nezahualcóyotl (UTN). Her professional experience has been focused on software development and technology support in education. She has been a facilitator of face-to-face, blended and distance learning environments for both bachelor's and master's degree programs. She obtained the Microsoft Office Specialist, Traditional Teaching Tutoring (CONOCER) and the Tutoring in Academic Transformation and Management Mentor (Harvard) certifications. She was the writing coordinator for the book Educational Teaching and Practical Competences in Distance Education, in which she authored the chapter "Competencies for OER production in b-learning environments". She participated as a speaker at the joint Iberoamerican Conference on Technologies and Learning 2014 and is collaborating on the development of standardized questions and answers for the CENEVAL (National Evaluation Center).

Tecnológico de Estudios Superiores de Chalco (TESCHA)

Carretera Federal México - Cuautla s/n

56641 La Candelaria Tlapala, Chalco

Mexico

RUSC Vol. 12 No. 1 | Universitat Oberta de Catalunya and University of New England | Barcelona, January 2015

@ B. J. García Espinosa, G. C. Tenorio Sepúlveda and M. S. Ramírez Montoya | @ by FUOC, 2015 | Self-motivation challenges for student involvement.. 
María Soledad Ramírez Montoya

solramirez@itesm.mx

Permanent research professor for Education, Humanities and Social Sciences and coordinator of innovation of educational models; Tecnológico de Monterrey. Chair of the open educational movement UNESCO offices

for Latin America and of ICDE OER Latin America

María Soledad Ramírez Montoya holds a PhD in Education from Salamanca University (Spain). Her research focuses are teaching strategies, digital resources for the education and training of educational researchers. She is chair of the open educational movement UNESCO offices for Latin America and of ICDE OER Latin America. She is the main investigator for the Network Strengthening Information Society Research Capacity Alliance (SIRCA), coordinator of educational models of Tecnológico de Monterrey and is the main organizer of the Latin American Open Regional Network of Social Research and Education (CLARISE).

Tecnológico de Monterrey

Edificio CEDES

Sótano 1 EGE Oficina CD-S1003-30

Garza Sada 2501

Monterrey, Nuevo León

Mexico 64849

Original title Retos de automotivación para el involucramiento de estudiantes en el movimiento educativo abierto con MOOC

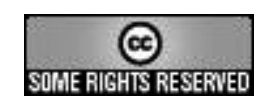

The texts published in this journal are - unless indicated otherwise - covered by the Creative Commons Spain Attribution 3.0 licence. You may copy, distribute, transmit and adapt the work, provided you attribute it (authorship, journal name, publisher) in the manner specified by the author(s) or licensor(s). The full text of the licence can be consulted here: <http://creativecommons.org/licenses/by/3.o/es/deed.en>

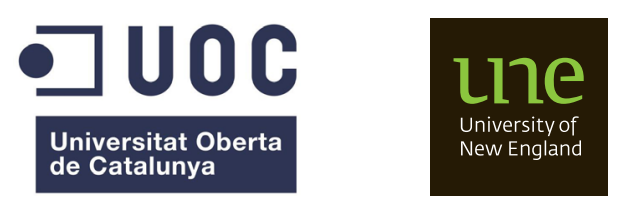

RUSC Vol. 12 No. 1 | Universitat Oberta de Catalunya and University of New England | Barcelona, January 2015 